\title{
Phytate degradation determines the effect of industrial processing and home cooking on iron absorption from cereal-based foods
}

\author{
Richard F. Hurrell ${ }^{1 *}$, Manju B. Reddy ${ }^{2}$, Joseph Burri ${ }^{3}$ and James D. Cook ${ }^{4}$ \\ ${ }^{1}$ Swiss Federal Institute of Technology, Zürich, Switzerland \\ ${ }^{2}$ Iowa State University, Department of Food Science and Human Nutrition, Ames, IA, USA \\ ${ }^{3}$ Nestlé Products Technology Centre, Orbe, Switzerland \\ ${ }^{4}$ Kansas University Medical Center, Kansas City, KS, USA
}

(Received 25 June 2001 - Revised 21 January 2002 - Accepted 24 February 2002)

\begin{abstract}
The aim of the present study was to compare Fe absorption from industrially-manufactured and home-cooked cereal foods. Fe absorption was measured using the radiolabelled Fe extrinsic tag technique in thirty-nine adult human subjects from cereal porridges manufactured by extrusion cooking or roller-drying, and from the same cereal flours after home cooking to produce pancakes, chappattis or bread. One series of cereal porridges was amylase-treated in addition before roller-drying. Fe absorption was relatively low from all products, ranging from $1.8-5.5 \%$ for rice, $2 \cdot 5-3.5 \%$ for maize, $4.9-13.6 \%$ for low-extraction wheat, and $<1 \%$ for high-extraction wheat foods. The phytic acid content remained high after drying of the cereal porridges being about $1 \cdot 20,1 \cdot 70,3 \cdot 20,3 \cdot 30 \mathrm{mg} / \mathrm{g}$ in low-extraction wheat, rice, high-extraction wheat and maize products respectively, and could explain the low Fe absorption. There were little or no differences in Fe absorption between the extruded and roller-dried cereals, although amylase pretreatment increased Fe absorption from the roller-dried rice cereal 3-fold. This was not due to phytate degradation but possibly because of the more liquid nature of the cereal meal as fed. There were similarly few or no differences in Fe absorption between the industriallyprocessed cereals and home-cooked cereals made into pancakes or chappattis. Bread-making, however, degraded phytic acid to zero in the low-extraction wheat flour and Fe absorption increased to $13.6 \%$, the greatest from all cereal foods tested. It is concluded that Fe absorption from extruded, roller-dried or home-cooked cereal foods is similarly low and that only those cooking procedures such as bread-making, which extensively degrades phytic acid, or amylase pre-treatment, which substantially liquifies cereal porridges, improve Fe absorption.
\end{abstract}

Iron absorption: Cereal-based foods: Industrial processing: Home cooking

Fe deficiency is widespread in infants, children and young women in both industrialised and developing countries (DeMaeyer \& Adiels-Tegman, 1985). A major factor in its aetiology is the poor absorption of Fe from cereal and legume-based staple foods (Taylor et al. 1995) due to their high level of phytic acid (myo-inositol-6-phosphate) (Reddy et al. 1982). Fe absorption from cereals, such as wheat, rice and maize, is low unless ascorbic acid (Cook et al. 1997) or EDTA (Hurrell et al. 2000) is added to counteract the potent inhibitory effect of phytic acid, or unless phytic acid is degraded or removed (Hallberg et al. 1987; Hurrell et al. 1992).

Phytic acid in foodstuffs can be degraded or removed during home cooking and by industrial processing, however, the influence of this lower phytic acid on Fe absorption has been little investigated. Milling of wheat, or polishing of rice grains, removes the bran and decreases phytic acid by up to $90 \%$ (Reddy et al. 1982). Traditional processes such as soaking, germination and fermentation can activate native grain phytases which degrade inositol6-phosphate to its lower forms. Soaking of legume seeds, such as peas, groundnuts and pigeon peas, has been reported to reduce phytic acid by about $20 \%$ (Bishnoi et al. 1994; Igbedioh et al. 1994), whereas germination of legume seeds or cereal grains reduced their phytic acid content by about half (Marero et al. 1991). Fermentation is more effective since the organic acids produced by the micro-organisms reduce the $\mathrm{pH}$ of the aqueous cereal mixture close to the optimum $\mathrm{pH}$ for phytase activity, and phytate degradation can be extensive or complete in 
products such as lactobacilli-fermented sorghum (Sharma \& Kapoor, 1996), soyabean tempeh (Sutardi \& Buckle, 1985) and bread made from low-extraction wheat flour (Daniels \& Fisher, 1981).

Conventional heat treatments, such as those used in domestic cooking or industrialised processing, have generally been reported to cause more moderate losses of phytic acid. Boiling or pressure cooking of mung bean or black gram resulted in a 5-15\% phytic acid loss (Kataria et al. 1988 , 1989), whereas with maize, boiling caused a $12 \%$ loss, making popcorn $18 \%$, charcoal roasting $42 \%$, and cooking a chappatti $53 \%$ (Khan et al. 1991). With the industrial process of extrusion cooking, losses of 10$30 \%$ have been reported for rye (Fretzdorf \& Weipert, 1986), rice and millet (Dublish et al. 1988), although the decrease was $50 \%$ with cow peas (Ummadi et al. 1994). Losses of up to $90 \%$ have been reported during the canning of beans (Tabekhia \& Luh, 1980). These phytate losses reported during the different cooking processes are presumably due to a combination of heat and/or enzyme degradation and of leaching of the phytic acid into the cooking water.

The aim of the present study was to compare the influence of extrusion cooking and roller-drying on $\mathrm{Fe}$ absorption from cereal porridges made from rice, maize, high-extraction wheat and low-extraction wheat flours, with and without an amylase pre-treatment to degrade the starch. This pre-treatment is often used in infant cereal manufacture to sweeten the product and to give the cereal a more free-flowing consistency. In addition, $\mathrm{Fe}$ absorption from the industrially-processed cereal porridges was compared with that from chappattis, pancakes or bread made from the same cereal flours. Fe absorption was measured by erythrocyte incorporation of radiolabelled $\mathrm{Fe}$ in adult human subjects using the radiolabelled $\mathrm{Fe}$ extrinsic tag technique (Cook et al. 1972).

\section{Subjects, methods and materials}

\section{Subjects}

Fe absorption was measured in thirty-nine volunteer subjects aged 19-39 years. The total group included eighteen males and twenty-one females. All subjects were in good health and denied a history of disorders known to influence the gastrointestinal absorption of Fe. Serum ferritin concentrations ranged from 3-118 $\mu \mathrm{g} / \mathrm{l}$ indicating a wide variation in Fe status. Seven of the subjects, one male and six females, were $\mathrm{Fe}$ deficient as defined by a serum ferritin concentration $<12 \mu \mathrm{g} / \mathrm{l}$. Written, informed consent was obtained from each volunteer before the investigation and all experimental procedures were approved by the Human Subjects Committee at the University of Kansas Medical Center. Subjects were allocated to the studies in the order in which they volunteered. There was no randomisation of male/female or of Fe status.

Four Fe absorption studies were made during which four separate $\mathrm{Fe}$ absorption measurements were performed in each of nine to ten subjects by using the dual radiolabelled Fe tracer technique, with tracers administered sequentially. All meals were administered between 07.00 hours and
09.00 hours after an overnight fast and nothing but water was allowed for $3 \mathrm{~h}$. The test meals were fed with a radiolabelled $\mathrm{Fe}$ tag, providing either $37 \mathrm{kBq}{ }^{59} \mathrm{Fe}$ or $74 \mathrm{kBq}$ ${ }^{55} \mathrm{Fe}$, and $\mathrm{Fe}$ absorption was measured based on erythrocyte enrichment as previously described (Cook et al. 1972).

On the day preceding administration of the first test meal, $25 \mathrm{ml}$ blood was collected from each subject into an EDTA-treated bottle for measurement of background radioactivity and packed cell volume. Blood $(5 \mathrm{ml})$ was collected in a tube with no additive, and serum ferritin (Flowers et al. 1986), and background radioactivity measured. The first and second test meals, labelled with ${ }^{55} \mathrm{Fe}$ and ${ }^{59} \mathrm{Fe}$ respectively, were fed on days 2 and 3 of the study. Fourteen days after the administration of the second of these meals (day 17), $30 \mathrm{ml}$ blood was drawn for the measurement of incorporated erythrocyte radioactivity. The third and fourth test meals, tagged with separate radiolabelled Fe labels, were fed on days 17 and 18 , and a final blood sample was obtained on day 32 to determine the increase in erythrocyte radioactivity. Measurements of blood radioactivity were performed on duplicate $10 \mathrm{ml}$ samples of whole blood by a modification of the method of Eakins \& Brown (1966). Briefly, after digesting whole blood in $\mathrm{HNO}_{3}, \mathrm{Fe}$ is precipitated twice with ammonium hydroxide and redissolved in phosphoric acid before finally precipitating with ammonium chloride and ethanol and suspending the precipitate in a scintillation gel for counting (Bothwell et al. 1979). Percentage absorption was calculated on the basis of blood volume estimated from height and weight (Wennesland et al. 1959; Brown et al. 1962) and an assumed erythrocyte incorporation of $80 \%$ (Hosein et al. 1967).

\section{Extruded and roller-dried cereal porridges}

Eleven experimental dried cereal porridges were prepared at the Nestlé Product Technology Centre, Orbe, Switzerland, using four different cereal flours and three different processing techniques. The cereal flours included rice flour from ground polished rice (origin Italy), partly degermed whole white maize flour (origin France), $80 \%$ extraction wheat flour and $60 \%$ extraction wheat flour (origin Switzerland). The high (80\%)-extraction wheat flour contained more bran than the low $(60 \%)$-extraction wheat flour. The first series of four flours were mixed with water to produce a mixture with $750 \mathrm{~g} \mathrm{DM} / \mathrm{kg}$, which was extruded on a twin-screw extruder. Extrusion is a high-temperature short-time process and maximum temperature and pressure reached were about $160^{\circ} \mathrm{C}$ and $10 \mathrm{Mpa}$, for a few seconds. The extrudate was then dried to $30 \mathrm{~g} \mathrm{moisture} / \mathrm{kg}$, and ground on a mill. The dried powder was mixed with sucrose $(100 \mathrm{~g} / \mathrm{kg}$ powder $)$. The second series of four flours were mixed with sucrose $(100 \mathrm{~g} / \mathrm{kg})$ and water to give a slurry of $400 \mathrm{~g} \mathrm{DM} / \mathrm{kg}$. The slurry was cooked by steam injection (about $135^{\circ} \mathrm{C}$ ) and roller-dried to reach a final moisture of $30 \mathrm{~g} / \mathrm{kg}$. The roller-dried flakes were ground to a powder. The third series of three flours (excluding the low-extraction wheat flour) were treated in a similar way to the second series but contained no added sugar. The product was sweetened by adding amylase and amyloglucosidase to convert part of 
the wheat starch to glucose and oligosaccharides. The enzyme hydrolysate was mixed with flour and further treated as for the roller-dried products (second series). Phytic acid was measured in all dried cereal porridges by a modification of the Makover (1970) method in which $\mathrm{Ce}$ replaced $\mathrm{Fe}$ in the precipitation step.

\section{Chappattis and pancakes}

High- and low-extraction wheat flours were made into chappattis. For ten high-extraction wheat flour chappattis, $225.0 \mathrm{~g}$ flour was mixed with $15.0 \mathrm{~g}$ corn oil, $3.0 \mathrm{~g}$ salt and $125.0 \mathrm{ml}$ water. The dough was kneaded by hand for $5 \mathrm{~min}$, divided into $35.0 \mathrm{~g}$ portions, which were left to stand for $10 \mathrm{~min}$ before rolling into discs and cooking in a frying pan over a high heat, turning several times.

The low-extraction wheat flour chappattis were cooked in a similar way but in a larger size. For ten low-extraction wheat flour chappattis, 500.0 g flour was mixed with $5.0 \mathrm{~g}$ salt, $3.5 \mathrm{~g}$ sugar and $250.0 \mathrm{ml}$ water. The dough was kneaded by hand, divided into ten equal portions of about $75.0 \mathrm{~g}$, which were rolled into discs and cooked in a frying pan over a high heat for about $30 \mathrm{~s}$.

The rice and maize flours were made into pancakes. For individual rice or maize pancakes, $22.5 \mathrm{~g}$ rice or maize flour was mixed with $0.25 \mathrm{~g}$ salt, $7.5 \mathrm{~g}$ sugar and $50.0 \mathrm{ml}$ water. The mixture was poured into a frying pan containing $2 \cdot 0 \mathrm{~g}$ corn oil and cooked over a medium heat for 2-3 min each side. The pancakes and the chappattis were wrapped in $\mathrm{Al}$ foil and refrigerated overnight.

\section{Bread rolls}

The low-extraction wheat flour was made into bread rolls. For ten bread rolls, 500.0 g flour was mixed with $5.0 \mathrm{~g}$ salt, $3.5 \mathrm{~g}$ sugar, $15.0 \mathrm{~g}$ yeast and $230.0 \mathrm{~g}$ water, kneaded mechanically in a food mixer for $30 \mathrm{~min}$, left to rise for
$2 \mathrm{~h}$ at a warm temperature, divided into twelve equal portions and baked at $220^{\circ} \mathrm{C}$ for $15 \mathrm{~min}$. After baking, the rolls were stored overnight at room temperature.

\section{Test meals}

The test meals fed in the four $\mathrm{Fe}$ absorption studies are shown in Table 1. In Study 1, Fe absorption was compared in subjects fed the rice porridge, either extruded (meal A), roller-dried (meal B), or amylase-treated and roller-dried (meal C), or fed the rice pancake (meal D). Studies 2 and 3 were identical to Study 1 except that in Study 2 the maize porridges and pancakes were fed, and in Study 3 the high-extraction wheat porridges and chappattis were fed. Study 4 was similar and compared Fe absorption from the low-extraction wheat flour porridge, either extruded (meal A) or roller-dried (meal B), with Fe absorption from a bread roll (meal C), or chappatti (meal D) made from the same flour. The bread roll was added as meal $\mathrm{C}$ in place of the amylase treated, roller-dried cereal so as to include a low-phytate meal.

All porridge meals consisted of $50.0 \mathrm{~g}$ dried cereal and $0.5 \mathrm{~g}$ salt mixed with $300.0 \mathrm{ml}$ hot water. The radioactive tag was added to the cereal meal as a $1.0 \mathrm{ml}$ solution containing $0.1 \mathrm{mg} \mathrm{Fe}$ as ferric chloride with either $74 \mathrm{kBq}{ }^{55} \mathrm{Fe}$ (meals $\mathrm{A}$ and $\mathrm{C}$ ) or $37 \mathrm{kBq}{ }^{59} \mathrm{Fe}$ (meal B) in $0.01 \mathrm{M}-\mathrm{HCl}$. The meals contained no added fortification with Fe. Sugar $(10.0 \mathrm{~g})$ was sprinkled on top of the porridge before serving. In order to ensure complete ingestion of the radiolabelled $\mathrm{Fe}$ tag mixed with cereals, the bowls were carefully rinsed with water after consumption of the meals and the rinsing water consumed.

The rice and maize pancakes were fed as meal $D$ in Studies 1 and 2 respectively. Each subject consumed two pancakes made from a total of about $45.0 \mathrm{~g}$ flour. The high- and low-extraction wheat flour chappattis were fed as meal D in Studies 3 and 4 respectively. Each subject

Table 1. Study meals and subject characteristics

\begin{tabular}{|c|c|c|c|c|c|c|c|}
\hline \multirow[b]{2}{*}{ Study } & \multirow[b]{2}{*}{ Meals } & \multirow[b]{2}{*}{$\begin{array}{l}\text { Phytic acid } \\
(\mathrm{mg} / \mathrm{g})^{*}\end{array}$} & \multicolumn{3}{|c|}{ Subjects } & \multirow[b]{2}{*}{$\begin{array}{l}\text { Packed cell } \\
\text { volume (\%) }\end{array}$} & \multirow[b]{2}{*}{$\begin{array}{l}\text { Serum ferritin } \\
(\mu \mathrm{g} / \mathrm{l}) \dagger\end{array}$} \\
\hline & & & $\begin{array}{l}\text { Males } \\
(n)\end{array}$ & $\begin{array}{c}\text { Females } \\
(n)\end{array}$ & $\begin{array}{c}\text { Age } \\
\text { (years) }\end{array}$ & & \\
\hline 1. Rice flour & $\begin{array}{l}\text { A Extruded } \\
\text { B Roller-dried } \\
\text { C Amylase-treated, roller-dried } \\
\text { D Pancake }\end{array}$ & $\begin{array}{c}1.74 \\
1.45 \\
1.92 \\
\text { na }\end{array}$ & 6 & 4 & 24 & 42 & $\begin{array}{c}27 \\
(5-73)\end{array}$ \\
\hline 2. Maize flour & $\begin{array}{l}\text { A Extruded } \\
\text { B Roller-dried } \\
\text { C Amylase-treated, roller-dried } \\
\text { D Pancake }\end{array}$ & $\begin{array}{c}3.35 \\
2.99 \\
3.53 \\
\text { na }\end{array}$ & 6 & 3 & 25 & 42 & $\begin{array}{c}27 \\
(3-78)\end{array}$ \\
\hline 3. High-extraction wheat flour & $\begin{array}{l}\text { A Extruded } \\
\text { B Roller-dried } \\
\text { C Amylase-treated, roller-dried } \\
\text { D Chappatti }\end{array}$ & $\begin{array}{c}3.89 \\
2.36 \\
3.44 \\
\text { na }\end{array}$ & 5 & 5 & 24 & 43 & $\begin{array}{c}62 \\
(26-111)\end{array}$ \\
\hline 4. Low-extraction wheat flour & $\begin{array}{l}\text { A Extruded } \\
\text { B Roller-dried } \\
\text { C Bread roll } \\
\text { D Chappati }\end{array}$ & $\begin{array}{c}1 \cdot 19 \\
1.22 \\
0.00 \\
\text { na }\end{array}$ & 1 & 9 & 26 & 42 & $\begin{array}{c}25 \\
(8-118)\end{array}$ \\
\hline
\end{tabular}

na, not analysed.

* Phytic acid content of dried cereal porridge and bread rolls. Each porridge meal consisted of $50.0 \mathrm{~g}$ dried cereal, $0.5 \mathrm{~g}$ salt and $300 \cdot 0 \mathrm{ml}$ water. For further details, see p. 119.

† Geometric mean values with ranges in parentheses. 
consumed two high-extraction wheat flour chappattis made from a total of about $45.0 \mathrm{~g}$ flour or one low-extraction wheat flour chappatti containing about $50.0 \mathrm{~g}$ flour. The bread roll containing about $50.0 \mathrm{~g}$ low-extraction wheat flour was fed as meal C in Study 4. Each subject consumed one roll. The radiolabelled Fe tag was added onto the surface of the chappatti or pancake and was pipetted into the interior of the roll, as a $1.0 \mathrm{ml}$ solution containing $0.01 \mathrm{mg}$ $\mathrm{Fe}$ as ferric chloride with either $74 \mathrm{kBq}{ }^{55} \mathrm{Fe}$ (meal C, bread roll) or $37 \mathrm{kBq}{ }^{59} \mathrm{Fe}$ (meal $\mathrm{D}$, pancakes, chappattis) in $0 \cdot 01 \mathrm{M}-\mathrm{HCl}$. Water was provided ad libitum with all meals.

\section{Statistical analysis}

Absorption percentage values were converted to logarithms for calculating geometric means and for statistical analysis. Original values were recovered by reconverting the results to antilogarithms (Layrisse et al. 1968). Comparison of $\mathrm{Fe}$ absorption for any given pair of test meals within each study was made by a paired $t$ test to determine whether the $\log$ absorption ratio differed from zero. Absorption values were adjusted to a common serum ferritin value of $30 \mu \mathrm{g} / \mathrm{l}$ (Cook et al. 1991) for comparison between studies (Graphpad Prism, San Diego, CA, USA). The absorption values were analysed by ANOVA and significant differences between groups were determined by Tukey's multiple comparison test. In all cases, a value for $P \leq 0.05$ was taken to indicate a significant difference.

\section{Results}

Mean Fe absorption by subjects consuming the cereal products was generally low irrespective of the cooking procedures and ranged from $1.8-5.5 \%$ for rice products, $2.9-3.5 \%$ for maize products, $4.9-13.6 \%$ for products made from low-extraction wheat flour, and $<1 \%$ for all products made from high-extraction wheat flour (Table 2). In general, subjects with a lower Fe status absorbed more $\mathrm{Fe}$ and vice versa, however, the mean absorption ratios reported are means of absorption ratios of individual subjects who consumed all four meals within each study. The influence of the different heat-processing techniques on Fe absorption was inconsistent and, with the exception of bread making, was either small or had no effect at all. When comparing extrusion with roller-drying, there were no significant differences in the mean $\mathrm{Fe}$ absorption by subjects fed either extruded or roller-dried cereals made from maize, high-extraction wheat flour or low-extraction wheat flour, although mean Fe absorption from extruded rice cereal was some $50 \%$ higher than the roller-dried product $(2.67$ v. $1.76 \%, P<0.01)$. Amylase treatment similarly increased $\mathrm{Fe}$ absorption 3-fold (5.49 v. $1.76 \%$, $P<0.01)$ from the roller-dried rice cereal and caused a non-significant $40 \%$ increase in absorption from the roller-dried maize and high-extraction wheat products.

Fe absorption from the home-cooked rice and maize pancakes or from high-extraction wheat chappattis was not significantly different from the respective extruded or roller-dried products. Fe absorption from low-extraction wheat flour chappattis was also not different from the extruded wheat cereal, although it was some $50 \%$ higher 
( 7.44 v. $4.92 \%, P<0.01)$ than from the roller-dried product. Mean Fe absorption from the wheat bread rolls made with low-extraction wheat flour $(13.6 \%)$ was the highest of all the cereal products tested and Fe was $2.4(P<0.01)$ and $2.8(P<0.001)$-fold better absorbed from the wheat roll than from the extruded or roller-dried low-extraction cereals respectively and 1.8 -fold higher $(P<0 \cdot 01)$ than the chappatti.

The phytic acid content of the dried cereal porridges is shown in Table 1. Levels in the low-extraction wheat products were lowest (about $1.20 \mathrm{mg} / \mathrm{g}$ ) followed by the rice cereals (about $1.70 \mathrm{mg} / \mathrm{g}$ ) with the maize cereals and high-extraction wheat products having a higher phytic acid content (about $3.30 \mathrm{mg} / \mathrm{g}$ ). The roller-dried products had on average a $16 \%$ lower phytic acid content than the equivalent extruded products, although these differences varied from zero in the low-extraction wheat products to $40 \%$ with the high-extraction wheat products. The amylase-treated roller-dried cereals similarly had an 18-45\% higher phytic acid content than the equivalent cereals roller-dried without amylase treatment. No phytic acid measurements were made on the pancakes, chappattis or non-heated cereal flours except for the low-extraction wheat flour, which had a phytic acid content of $1.44 \mathrm{mg} /$ g. The phytic acid content in the bread roll made from this flour was undetectable, indicating a complete degradation during the bread-making process.

\section{Discussion}

Fe absorption from cereal foods is strongly related to their phytic acid content and is generally higher in foods with a lower phytic acid content (Cook et al. 1997). Any industrial or home-cooking procedure which degrades or removes phytic acid could therefore increase Fe absorption. In our present study, the only cooking procedure that had a major effect on Fe absorption was a breadbaking process which included a yeast fermentation step and which reduced phytic acid to zero. Fe absorption in subjects consuming the bread roll was 2-3-fold higher than when the same subjects consumed a chappatti or an extruded or roller-dried cereal porridge made from the same low-extraction wheat flour. When interpreting the absorption results (Table 2), it should be remembered that, within each study, each subject was fed all four meals. The absorption ratios of one meal relative to another can therefore be expected to largely overcome any influence of the subjects' Fe status on the level of Fe absorption.

Phytic acid is a potent inhibitor of Fe absorption even at low concentrations. In a soyabean-isolate formula meal, phytic acid had to be degraded by up to $95 \%$ so as to provide $<10 \mathrm{mg}$ phytic acid per meal before a meaningful increase in Fe absorption was observed (Hurrell et al. 1992). Similarly, when free phytate was added to bread rolls, amounts as low as $7 \mathrm{mg}$ per roll reduced Fe absorption by about $20 \%$ and $35 \mathrm{mg}$ reduced Fe absorption by some $60 \%$ (Hallberg et al. 1989).

The roller-dried and extruded cereal porridges were fed as $50 \mathrm{~g}$ servings and provided about $60-200 \mathrm{mg}$ phytic acid per meal. It is not surprising, therefore, that Fe absorption from these products was low. Although the roller-dried cereals contained in general somewhat less phytate than the extruded products, this difference was too small to influence $\mathrm{Fe}$ absorption. Extrusion cooking and rollerdrying of the low-extraction wheat flour caused only a $20 \%$ loss in phytate, which is similar to that reported in other studies (Dublish et al. 1988). Extrusion cooking has previously been reported not to influence $\mathrm{Fe}$ absorption from high-phytate cereals (Kivisto et al. 1986; Fairweather-Tait et al. 1989). It should be noted that ascorbic acid counteracts the negative effect of phytic acid on $\mathrm{Fe}$ absorption (Hallberg et al. 1989), and that infant cereal manufacturers often add ascorbic acid so as to optimise the absorption of fortification Fe (Hurrell, 1999).

The significantly higher absorption from the extruded rice cereal compared with the equivalent roller-dried product is difficult to explain since the phytic acid content of the extruded cereal was higher. It is possible that the physical nature of the cereal or the consistency of the porridge played a role. This is also a possible explanation for the 3-fold higher absorption from the amylase-treated rollerdried rice cereal compared with the same product without amylase treatment, and for the slightly higher Fe absorption values obtained with the other amylase-treated products. Amylase treatment, by hydrolysing the cereal starch, gives a more free-flowing and liquid product on addition of water. This is in contrast to the thicker porridge formed with the non-amylase-treated cereals. In our present study, the amylase-treated cereals were fed as a drink in a cup rather than as a porridge in a bowl. It is well known that food per se reduces Fe absorption. Fe absorption from water, for example, was reduced 3-fold when consumed with a phytate-free bread roll (Hurrell et al. 1999). Presumably Fe binds in some way to the degradation products formed on the digestion of the carbohydrate, protein and fat components of the meal.

In general, there were no differences in $\mathrm{Fe}$ absorption between the industrially-processed cereal porridges and the home-prepared pancakes or chappattis made from the same cereal flours. This would indicate that phytic acid was not more degraded on home cooking than on industrial processing, or at least not degraded sufficiently to improve absorption. The only exception was the low-extraction wheat chappattis from which Fe absorption was $50 \%$ higher than the equivalent roller-dried product. Chappatti making has been reported to reduce phytic acid in maize by some $50 \%$ (Khan et al. 1991), so phytic acid degradation could be the explanation. The reason why the high-extraction wheat chappatti did not have an improved Fe absorption could be due to its much higher initial phytate content. Similarly, the much gentler heating treatment used to make the pancakes may have degraded phytic acid to a lesser extent.

Our present studies were made with cereal foods containing no fortification Fe. Although, the Fe content was not measured, it can be expected to be about $10-20 \mathrm{mg} /$ $\mathrm{kg}$ flour. Enriched cereal flours contain about $40 \mathrm{mg} \mathrm{Fe} /$ $\mathrm{kg}$ and fortified infant cereals from $100-500 \mathrm{mg} \mathrm{Fe} / \mathrm{kg}$. The influence of phytic acid on Fe absorption depends on the phytic acid:Fe molar ratio of the meal. Phytic acid begins to lose its inhibitory effect at phytic acid:Fe molar ratios $<1 \cdot 0: 1 \cdot 0$, although it still inhibits at ratios as low 
as 0.2:1.0 (Hallberg et al. 1989; Hurrell et al. 1992). Some highly Fe-fortified foods may have ratios $<1.0$ and the influence of processing on Fe absorption from these products may be different from the influence of processing on Fe absorption from non-fortified cereal foods. However, since most industrial processes had only a minor effect on phytic acid content, the relative effect on Fe absorption should not be affected.

In conclusion, $\mathrm{Fe}$ absorption was relatively low from extruded, roller-dried or home-cooked maize, rice and wheat flours, presumably because of the relatively high amount of phytic acid that still remained after the processing or home preparation. There was little or no difference in $\mathrm{Fe}$ absorption from extruded or roller-dried cereals, except when amylase pre-treatment was used. The amylase-treated product formed a soup instead of a porridge on addition of water, and this liquid consistency may be responsible for the higher absorption observed. Similarly, there were few or no differences in $\mathrm{Fe}$ absorption from the industrially-prepared cereal porridges as compared with the home-cooked pancakes or chappattis made from the same flour. The only cereal product where processing considerably increased Fe absorption was the bread roll. The high Fe absorption from the bread roll was presumably due to the complete degradation of phytic acid during bread making.

\section{References}

Bishnoi S, Khetarpaul N \& Yadav RK (1994) Effects of domestic processing and cooking methods on phytic acid and polyphenol contents of pea cultivars (Pisum sativum). Plant Food for Human Nutrition 45, 381-388.

Bothwell TH, Charlton RW, Cook JD \& Finch CA (1979) Iron Metabolism in Man. Oxford: Blackwell Scientific Publications.

Brown E, Hopper J Jr, Hodges JL Jr, Bradley B, Wennesland R \& Yamauchi H (1962) Red cell, plasma, and blood volume in healthy women measured by radiochromium cell-labelling and hematocrit. Journal of Clinical Investigation 41, 2188-2190.

Cook JD, Dassenko SA \& Lynch SR (1991) Assessment of the role of non-heme iron availability in iron balance. American Journal of Clinical Nutrition 54, 717-722.

Cook JD, Layrisse M, Martinez-Torres C, Monsen E \& Finch CA (1972) Food iron absorption measured by an extrinsic tag. Journal of Clinical Investigation 51, 805-815.

Cook JD, Reddy MB, Burri J, Juillerat MA \& Hurrell RF (1997) The influence of different cereal grains on iron absorption from infant cereal foods. American Journal of Clinical Nutrition $\mathbf{6 5}$, 964-969.

Daniels DHG \& Fisher N (1981) Hydrolysis of the phytate of wheat flour during bread baking. British Journal of Nutrition 46, 1-6.

DeMaeyer E \& Adiels-Tegman M (1985) The prevalence of anaemia in the world. World Health Statistics Quarterly 38, $302-316$.

Dublish RK, Chanhan GS \& Bains GS (1988) Nutritional quality of extruded rice, ragi and defatted soy flour blends. Journal of Food Science and Technology 25, 35-38.

Eakins JD \& Brown DA (1966) An improved method for the simultaneous determination of iron-55 and iron-59 in blood by liquid scintillation counting. International Journal of Applied Radiation and Isotopes 17, 391-397.

Fairweather-Tait SJ, Portwood DE, Symss LL, Eagles J \& Minski
MJ (1989) Iron and zinc absorption in human subjects from a mixed meal of extruded and non-extruded wheat bran and flour. American Journal of Clinical Nutrition 49, 151-155.

Flowers CA, Kuizon M, Beard JL, Skikne BS, Covell AM \& Cook JD (1986) A serum ferritin assay for prevalence studies of iron deficiency. American Journal of Hematology 23, $141-151$.

Fretzdorff B \& Weipert D (1986) Phytinsäure in Getreide und Getreideerzeugnissen. Mitteilung 1. Phytinsäure und Phytase in Roggen und Roggenprodukt (Phytic Acid in Cereals and Cereal Products. Part 1. Phytic Acid and Phytase in Rye Products). Zeitung für Lebensmittel Untersuchung und Forschung 182, 287-293.

Hallberg L, Brune M \& Rossander L (1989) Iron absorption in man: ascorbic acid and dose-dependent inhibition by phytate. American Journal of Clinical Nutrition 49, 140-144.

Hallberg L, Rossander L \& Skanberg A-B (1987) Phytates and the inhibitory effect of bran on iron absorption in man. American Journal of Clinical Nutrition 45, 988-996.

Hosein F, Marsaglia G \& Finch CA (1967) Blood ferrokinetics in normal man. Journal of Clinical Investigation 46, 1-9.

Hurrell RF (1999) Iron. In The Mineral Fortification of Foods, 1st ed., pp. 54-93 [RF Hurrell, editor]. Leatherhead: Leatherhead Publishing.

Hurrell RF, Juillerat MA, Reddy MB, Lynch SR, Dassenko SA \& Cook JD (1992) Soy protein, phytate and iron absorption in man. American Journal of Clinical Nutrition 56, 573-578.

Hurrell RF, Reddy M \& Cook JD (1999) Inhibition of non-haem iron absorption in man by polyphenolic-containing beverages. British Journal of Nutrition 81, 289-295.

Hurrell RF, Reddy MB, Burri J \& Cook JD (2000) An evaluation of EDTA compounds for iron fortification of cereal-based foods. British Journal of Nutrition 84, 903-910.

Igbedioh SO, Kehinde T \& Akpapunam MA (1994) Effect of processing methods on phytic acid level and some constituents in bambara groundnut (Vigna subterranea) and pigeon pea (Cajanus cajan). Food Chemistry 50, 147-151.

Kataria A, Chauhan BM \& Gandhi S (1988) Effect of domestic processing and cooking on the antinutrients of black gram. Food Chemistry 30, 149-156.

Kataria A, Chauhan BM \& Punia D (1989) Antinutrients and protein digestibility (in vitro) of mungbean as affected by domestic processing and cooking. Food Chemistry 32, 9-17.

Khan N, Zaman R \& Elahi M (1991) Effect of heat treatments on the phytic acid content of maize products. Journal of the Science of Food and Agriculture 54, 153-156.

Kivisto B, Andersson H, Cederblad G, Sandberg A-S \& Sandström B (1986) Extrusion cooking of a high cereal product. 1. Effects on apparent absorption of zinc, iron, calcium, magnesium and phosphorus in humans. British Journal of Nutrition 55, 255-260.

Layrisse M, Cook JD, Martinez-Torres C, Roche I, Kuhn N, Walker RB \& Finch CA (1968) Food iron absorption: A comparison of vegetable and animal foods. Blood 33, 430-443.

Makover RU (1970) Extraction and determination of phytic acid in beans. Cereal Chemistry 47, 288-295.

Marero LM, Payumo EM, Aguinaldo AR, Matsumoto I \& Homma S (1991) The antinutritional factors in weaning foods prepared from germinated legumes and cereals. Lebensmittelwissenschaft und -technologie 24, 177-181.

Reddy NR, Sathe SK \& Salunkhe DK (1982) Phytate in legumes and cereals. Advances in Food Research 28, 1-92.

Sharma A \& Kapoor AC (1996) Levels of antinutritional factors in pearl millet as affected by processing treatment and various types of fermentation. Plant Foods for Human Nutrition 49 , $241-252$.

Sutardi \& Buckle KA (1985) Reduction of phytic acid levels in 
soybeans during tempeh production, storage and frying. Journal of Food Science 59, 260-263.

Tabekhia MM \& Luh BS (1980) Effect of germination, cooking and canning on phosphorus and phytate retention in dry beans. Journal of Food Science 45, 406-408.

Taylor PG, Mendez-Castellanos H, Martinez-Torres C, Jaffe W, Lopez de Blanco M, Landaeta-Jimenez M, Leets I, Tropper E, Ramirez J, Casal M \& Layrisse M (1995) Iron bioavailability from diets consumed by different socioeconomic strata of the Venezuelan population. Journal of Nutrition 125, $1860-1868$
Ummadi P, Chenoweth WL \& Uebersax MA (1994) The influence of extrusion processing on iron dialysability, phytates and tannins in legumes. Journal of Food Processing and Preservation 19, 119-131.

Wennesland R, Brown E, Hopper J, Hodges JL Jr, Guttentag OE, Scott KG, Jucker IN \& Bradley B (1959) Red cell, plasma and blood volume in healthy men measured by radiochromium $\left(\mathrm{Cr}^{51}\right)$ cell tagging and hematocrit: influence of age, somatotype and habits of physical activity on variance after regression of volumes to height and weight combined. Journal of Clinical Investigation 38, 1065-1077. 